LA-UR- $12-0 / K / 1$

Approved for public release;

distribution is unlimited.
Title:

Production of Double-Sided Targets by Electrodeposition: Initial Evaluation and Optimization of Performance

\author{
Author(s): Evelyn M. Bond, W. Allen Moody, Todd A. Bredeweg \\ Intended for: \\ Methods and Applications of Radioanalytical Chemistry IX \\ (MARC IX). \\ March 25-30 \\ Kailua-Kona, HI USA
}

Los Alamos National Laboratory, an affirmative action/equal opportunity employer, is operated by the Los Alamos National Security, LLC for the National Nuclear Security Administration of the U.S. Department of Energy under contract DE-AC52-06NA25396. By acceptance of this article, the publisher recognizes that the U.S. Government retains a nonexclusive, royalty-free license to publish or reproduce the published form of this contribution, or to allow others to do so, for U.S. Government purposes. Los Alamos National Laboratory requests that the publisher identify this article as work performed under the auspices of the U.S. Department of Energy. Los Alamos National Laboratory strongly supports academic freedom and a researcher's right to publish; as an institution, however, the Laboratory does not endorse the viewpoint of a publication or guarantee its technical correctness. 
Log Number 375

Production of Double-Sided Targets by Electrodeposition: Initial Evaluation and Optimization of Performance

\author{
E. M. Bond ${ }^{1}$ \\ bond@lanl.gov, fax 505-665-4955 \\ W. A. Moody ${ }^{1}$ \\ T. A. Bredeweg ${ }^{1}$
}

1. C-NR, MS J-514, Los Alamos National Laboratory, Los Alamos, NM 87545, USA 


\title{
Production of Double-Sided Targets by Electrodeposition: Initial Evaluation and Optimization of Performance
}

\author{
E. M. Bond, W. A. Moody, T. A. Bredeweg \\ 1. C-NR, MS J-514, Los Alamos National Laboratory, Los Alamos, NM 87545, USA
}

\begin{abstract}
The Detector for Advanced Neutron Capture Experiments (DANCE) located at the Los Alamos Neutron Science Center (LANSCE) is used to perform neutron capture cross section measurements on radioactive and nonradioactive isotopes. Thin actinide targets for the DANCE detector are typically prepared by molecular deposition on thin titanium foils. For the preparation of double-sided deposits, a Teflon electrodeposition cell was constructed with two liquid chambers with a foil substrate in between, allowing electrodeposition on both sides of the foil. We have been studying the electrodeposition of uranium from isopropyl alcohol solutions using this cell. Effects of acid composition, uranium concentration, current, and deposition time will be described.
\end{abstract}

\section{Keywords}

DANCE, electrodeposition, uranium, molecular plating

\section{Introduction}

The Detector for Advanced Neutron Capture Experiments (DANCE) is located at the Los Alamos Neutron Science Center (LANSCE) at Los Alamos National Laboratory (LANL). DANCE is composed of $160 \mathrm{BaF}_{2}$ crystals arranged in a $4 \pi$ geometry and was designed to measure neutron capture reactions on small samples of radioactive or non-radioactive nuclides under high energy neutron fluences. Measurements taken with DANCE are useful for stockpile stewardship, advanced reactor design, and nuclear forensics. Additional details of the DANCE detector are described elsewhere.[1,2].

Since the installation of DANCE in 2002, successful nuclear cross-section measurements have been achieved $[3,4]$. The target materials for these experiments have typically been prepared by electrodeposition on thin titanium foil and the preparation of these have been described in the literature for ${ }^{75} \mathrm{As}[5],{ }^{173} \mathrm{Lu}[6],{ }^{233} \mathrm{U}[7,8],{ }^{235} \mathrm{U}$ $[8],{ }^{237} \mathrm{~Np}[4],{ }^{241} \mathrm{Am}[7,8]$, and ${ }^{243} \mathrm{Am}[8]$. One of the challenges with preparing targets for cross section measurement is that thick, uniform targets must be prepared with good adhesion to the substrate material. In some cases, it may be difficult to achieve the goal of $500-1000 \mathrm{ug} / \mathrm{cm}^{2}$ that may be desired for cross-section measurements. Targets prepared on both sides of the substrate material would help achieve this goal by doubling 
the electrodeposited material; however, with the electrodeposition cells available at LANL, such deposits could only be prepared by two separate electrodepositions. We have been able to prepare electrodeposits one side at a time with stable (non-radioactive) compounds (unpublished work with Lu), however depositions on two sides involved electrodeposition on one side of a thin foil, disassembly of the cell, drying of the target, reassembly of the cell, and then another electrodeposition. With highly radioactive compounds this task was very difficult using our standard electrodeposition cell. Furthermore, thin and often delicate Ti foils are preferred for cross-section targets; the less these foils are handled, the more likely it is that they will survive intact for the nuclear cross-section measurements; these foils are easily torn, adhere to heated surfaces, and become severely wrinkled. Colleagues at Lawrence Livermore National Laboratory have developed a double-sided electrodeposition cell [9] and they have graciously provided us with the plans for the manufacture of this device. A double-sided electrodeposition cell was constructed and we have conducted experiments to determine the optimum conditions for electrodeposition of this device with uranium.

\section{Experimental}

The double-sided electrodeposition cell was constructed from Teflon using plans provided by LLNL with a few minor changes. Henderson et al [9] have provided a schematic in Figure 6 of their paper. The cell aperture was 5.3 $\mathrm{mm}$ in diameter, the deposit sizes were measured as $5 \mathrm{~mm}$ in diameter. The cell aperture was also moved up from the center to 1.0625 inches from the center of the aperture to the top.

The volume of each side of the cell was $30 \mathrm{~mL}$ (Figure 1). Electrodepositions were carried out at constant current, using a Fisher FB300 power supply. All acids were tracer grade or better. The isopropyl alcohol was from Alfa Aesar. All of the deposits were prepared on 1 mil thick rolled titanium stock. The uranium was a solution of low enriched uranium in $0.1 \mathrm{M} \mathrm{HNO}_{3}$ obtained from LANL stocks. For the electrodeposition studies, a molecular plating procedure used at LANL $[7,8]$ was adapted for use in the double-sided electrodeposition cell.

\section{Effect of acid concentration}

For this study, $25 \mathrm{~mL}$ isopropyl alcohol, $0.625 \mathrm{~mL}$ uranium in $0.1 \mathrm{M} \mathrm{HNO}_{3}$ and $0.625 \mathrm{~mL} 0.1 \mathrm{M} \mathrm{HCl}$ were placed in each side of the cell. Additional or decreased amounts of acid solutions were added to the cell in order to assess the effect that these acids had upon the yield. The electrodepositions were carried out for 30 minutes; the power supply was set to $30 \mathrm{~m} \AA$, although the current remained below this set point for most of this series of 
experiments. At the end of the electrodeposition, $3.125 \mathrm{~mL}$ concentrated ammonium hydroxide were added to each side and the electrodeposition continued for one minute. Once finished, the contents of the cells were removed, rinsed with deionized water, and the cells dissembled. The Ti substrate was then carefully placed on a planchet and dried at $120^{\circ} \mathrm{C}$ on a hotplate.

Effect of time and current

For these series of experiments, $22 \mathrm{~mL}$ isopropyl alcohol, $0.625 \mathrm{~mL}$ uranium in $0.1 \mathrm{M} \mathrm{HNO}_{3}, 0.625 \mathrm{~mL} 0.1$ $\mathrm{M} \mathrm{HCl}$ and $4.375 \mathrm{~mL} 0.01 \mathrm{M} \mathrm{HNO}_{3}$ were placed into each side of the cell. For the time dependence study, the electrodepositions were conducted for 15-240 minutes at $30 \mathrm{~m} \AA$ constant current. For the current dependence study, 60 and 120 minute electrodeposition time were used and the current was varied from $30-75 \mathrm{~m} \AA$. At the end of the electrodeposition the cell was quenched and the electrodeposition was ended as described above. For the 120 and 240 minute electrodepositions, additional electrodeposition solution, using the same ratio of isopropyl alcohol, 0.1 $\mathrm{M} \mathrm{HNO}_{3}$ and $0.1 \mathrm{M} \mathrm{HCl}$ that were used above, was added to each side of the cell to maintain the solution level above the cathode surface. For the current study, the constant current goal was not achieved immediately upon the start of the electrodeposition, but was achieved within the first half hour. At the higher current intensities, the rate of evaporation was increased. The electrodeposition cell was monitored and additional isopropyl alcohol was added as needed to keep the solution level above the top of the cathode.

\section{Effect of uranium concentration}

The same basic conditions as described above for the time and current studies were used for the measurement of the effect of uranium concentration on yield and sample thickness except that the electrodeposition time was 120 minutes and the amount of uranium added to the cell was varied.

The uranium deposits were counted using a SAC-4 alpha counter made by Eberline Instruments. Each side of the uranium deposits prepared for the effect of acid study were counted for 10 minutes; all others were counted for 20 minutes; the data for each side were averaged; the uncertainties were based on the counting error for each deposit.

Autoradiography was conducted using a GE FLA 7000 Autoradiography system using an image plate scanner with type TR image plates with $25 \mu \mathrm{m}$ resolution. ImageQuant TL software was used to analyze the images. 


\section{Results and Discussion}

For the electrodeposition experiments, we started with the same procedure used previously $[7,8]$, however the volumes were scaled to accommodate the larger volume of the double-sided electrodeposition cell. We began the study of the electrodeposition of uranium with this cell by the examination of the effect of acid concentration upon the yield of uranium (Figure 2). The yields were low and the thicknesses of the uranium deposits for each side ranged from 97 to $161 \mathrm{ug} / \mathrm{cm}^{2}$. The effect of the acid was modest; the increase in the amount of $0.1 \mathrm{M} \mathrm{HCl}$ solution did not significantly affect the yield. However, there was an increase in yield when the amount of $0.1 \mathrm{M} \mathrm{HNO}_{3}$ was increased. It was observed that the power supply could not achieve the $30 \mathrm{~m} \AA$ set point during these experiments; the additional acid solution increased the current observed during these experiments from $\sim 2 \mathrm{~m} \AA$ to $\sim 24 \mathrm{~m} \AA$ for the highest nitric acid amount. For the subsequent experiments, this higher amount of $0.1 \mathrm{M} \mathrm{HNO}_{3}(5 \mathrm{~mL})$ was used and the amount of isopropyl alcohol was decrease to accommodate the greater volumes. Under these conditions, the constant current setting of $30 \mathrm{~m} \AA$ was achieved within a few minutes of starting the electrodeposition.

The effect of time on the electrodeposition yield was studied next (Figure 3). A linear increase in yield as a function of time is observed up to 120 minutes and then the rate of increase sharply drops off between 120 minutes and 240 minutes. The electrodeposition time had a greater impact upon the yield than increasing the acid concentration experiment described above. The amount electrodeposited at 120 minutes was 2.6 times greater than the yield for the initial deposits prepared at 30 minutes. Based on these data, we adopted 120 minutes as the standard electrodeposition time for the rest of the experiments.

The effect of current on the electrodeposition yield was examined at 60 and 120 minutes (Figure 4). There was a small, but significant increase in deposit yield at 60 minutes; the deposit thicknesses respectable: 230 to 280 $\mathrm{ug} / \mathrm{cm}^{2}$ uranium per side. The yield was significantly increased as the current was changed from 30 to $75 \mathrm{~mA}$; deposit yields were quite good and the deposit thickness was increased from $400 \mathrm{ug} / \mathrm{cm}^{2}$ to $580 \mathrm{ug} / \mathrm{cm}^{2}$ uranium per side. One potential detrimental effect that was noted during these electrodepositions is that as the current was increased, the evaporation of the electrodeposition cell increased, requiring more frequent additions of supplemental isopropyl alcohol.

Next, in an effort to push the limit of deposit thickness, the amount of uranium added to the cell was increased (Figure 5). There was not a statistically significant different in the yields observed for these series of 
electrodepositions. However, there was a dramatic increase in the uranium thickness as the uranium concentration increased; the increase in thickness was linear over the range studied. Because of the surface uniformity issues described below, additional experiments with even higher amounts of uranium were not pursued, although it would certainly be interesting to determine the maximum loading that can be achieved with uranium using this cell. The deposit thickness of $1460 \mathrm{ug} / \mathrm{cm}^{2}$ (per side) achieved in this study exceeded the thickness we had previously reported for ${ }^{233} \mathrm{U}$ and ${ }^{235} \mathrm{U}[7,8]$.

Visual inspection of the deposits after electrodeposition sometimes revealed inhomogeneities in the surfaces; a thinner area was often found at the top of the deposit. The samples described above for the current study were examined by autoradiography. Based on the autoradiography, there was no correlation between the current used and the degree of uniformity. Figure 6 shows the autoradiographs of the two sides of the deposit prepared at 120 minutes, $60 \mathrm{~m} \AA$. There is clearly an area at the top of the deposit, particularly in the "front" side of the target. The bare area is believed to be the result of bubbles that are generated during the course of electrodeposition that remain trapped (Figure 7a). Although these bubbles are generated during all of the electrodepositions, not all of the deposits had these bare areas. It is possible that the minor agitation caused by the addition of supplemental isopropyl alcohol is sufficient to dislodge the bubbles in some cases.

One idea to remove the trapped bubbles was to redesign the cell so that bubbles generated during the electrodeposition can escape. The idea is illustrated in Figure $7 \mathrm{~b}$; the Teflon surface will be machined so that a wider opening up to the $\mathrm{Ti}$ substrate is formed, leaving enough wall to permit support of the O-ring. The relevant parts of the cell have been returned to the machine shop and the cell will be tested once the modifications have been made. Another method to reduce the bubble formation is through mixing of the solutions during electrodeposition. Henderson et al use a peristaltic pump [9], however due to administrative and space considerations, we did not attempt these electrodepositions with stirring.

\section{Conclusions}

We have tested the double sided electrodeposition cell and have modified the conditions so that thick deposits of uranium can be prepared on both sides of the target substrate. By alterations of the conditions, the yields and thicknesses of the samples have improved to produce thicker targets than we had achieved using the single-sided electrodeposition system. Through autoradiography, we have determined that a consistent bare spot is found at the top of these deposits; we hope to improve the uniformity of the deposits either by redesign of the cell or through 
mixing or agitation of the cell during electrodeposition. We expect to use this cell to prepare targets for upcoming DANCE experiments.

\section{Acknowledgments}

We would like to express our gratitude to C. Y. Wu for the plans for the electrodeposition cell and R. A. Henderson for the helpful advice that he has provided. The authors would also like the express gratitude to the Mr. Arthur Montoya and C-NR machine shop for construction of the electrodeposition cell at to Mr. Mark Smith of the C-NR countroom for the autoradiographs. This measurement is supported out the stockpile stewardship program by DOE/NNSA under the auspices of the US Department of Energy at Los Alamos National Laboratory by the Los Alamos National Security LLC, Contract No. DE-AC52-06NA25396.

\section{References}

1. Heil M, Reifarth R, Fowler MM, Haight RC, Käppler F, Rundberg RS, Seabury EH, Ullmann JL, Wilhelmy JB, Wisshak, K (2001) Nucl Instrum Meth A 459:229-246.

2. Reifarth R, Esch E-I, Alpizar-Vicente A, Bond EM, Bredeweg TA, Glover SE, Greife U, Hatarik R, Haight RC, Kronenberg A, O'Donnell JM, Rundberg RS, Schwantes JM, Ullmann JL, Vieira DJ, Wouters JM (2005) Nucl. Instrum. Meth. B, 241 176-179.

3. Jandel M, Bredeweg, TA, Bond EM, Chadwick MB, Clement RR, Couture A, O'Donnell, JM, Haifght RC, Kawano T, Reifarth, R, Rundberg, RS, Ullmann, JL, Vieira, DJ, Wilhelmy, JB, Wouters, JM, Agvaanluvsan, U, Parker, WE, Wu, CY. Becker JA

4. Esch E-I, Reifarth R, Bond EM, Bredeweg, TA, Couture A, Glover SE, Greife U, Haight RC, Hatarik AM, Hatarik R, Jandel M, Kawano T, Mertz A, O'Donnell JM, Rundberg RS, Schwantes JM, Ullmann JL, Vieira DJ, Wilhelmy JB, Wouters JM (2008) Phys Rev C 77: 034309

5. Fassbender M, Bach H, Bond E, Nortier FM, Vieira D (2009) J Radioanal Nucl Chem 282:365-368.

6. Taylor WA, Rundberg RS, Bond EM, Nortier FM, Vieira DJ (2009) J Radioanal Nucl Chem 282:391-394

7. Bond, EM, Bredeweg TA, FitzPatrick JR, Jandel, M. Rundberg RS, Slemmons AK, Vieira DJ (2009) 282: 379384.

8. FitzPatrick JR, Bond E, Slemmons A, Vieira D (2008) J Radioanal Nucl Chem 276:561-566.

9. Henderson RA, Gostic JM, Burke JT, Fisher SE, Wu CY (2011) Nucl Instrum Methods Phys Res A 655:66-71. 
Figure 1. The electrodeposition cell during a sample preparation.

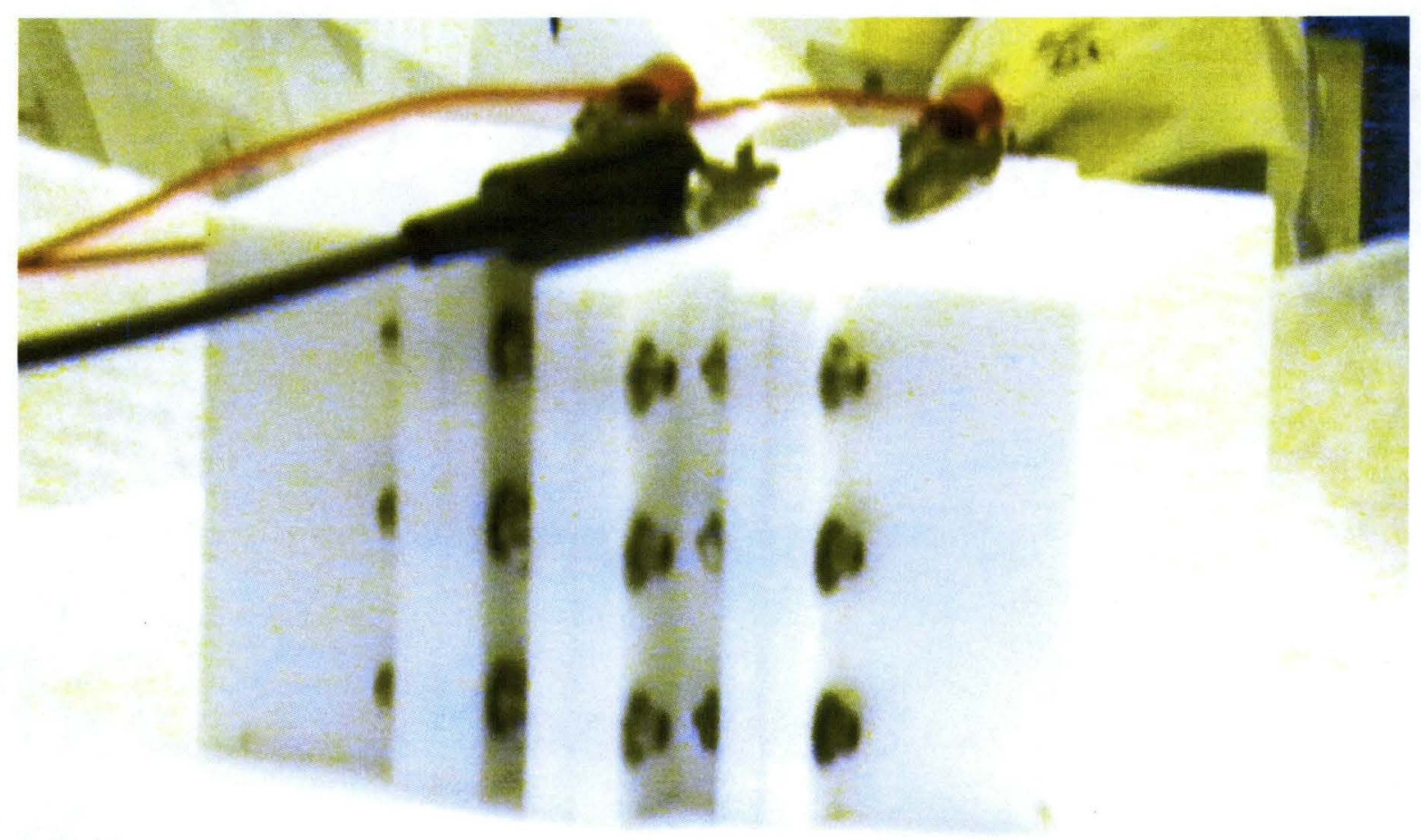


Figure 2. Graph of the effect on \% Yield of uranium by the amount of $0.1 \mathrm{M} \mathrm{HCl}$ or $0.1 \mathrm{M} \mathrm{HNO}_{3}$ added to each side of the electrodeposition cell.

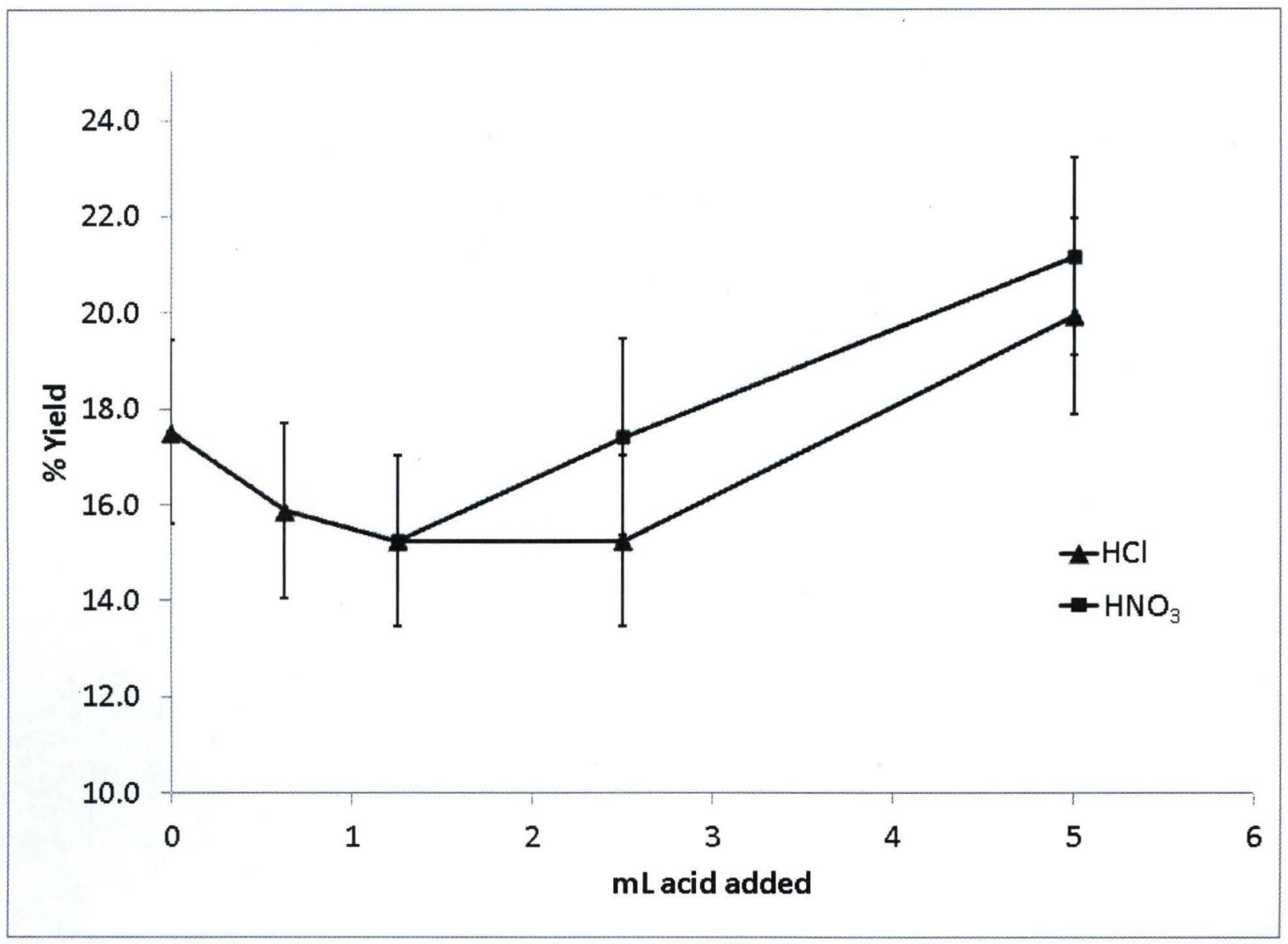


Figure 3. Graph of the change in the yield of uranium electrodeposition as a function of time.

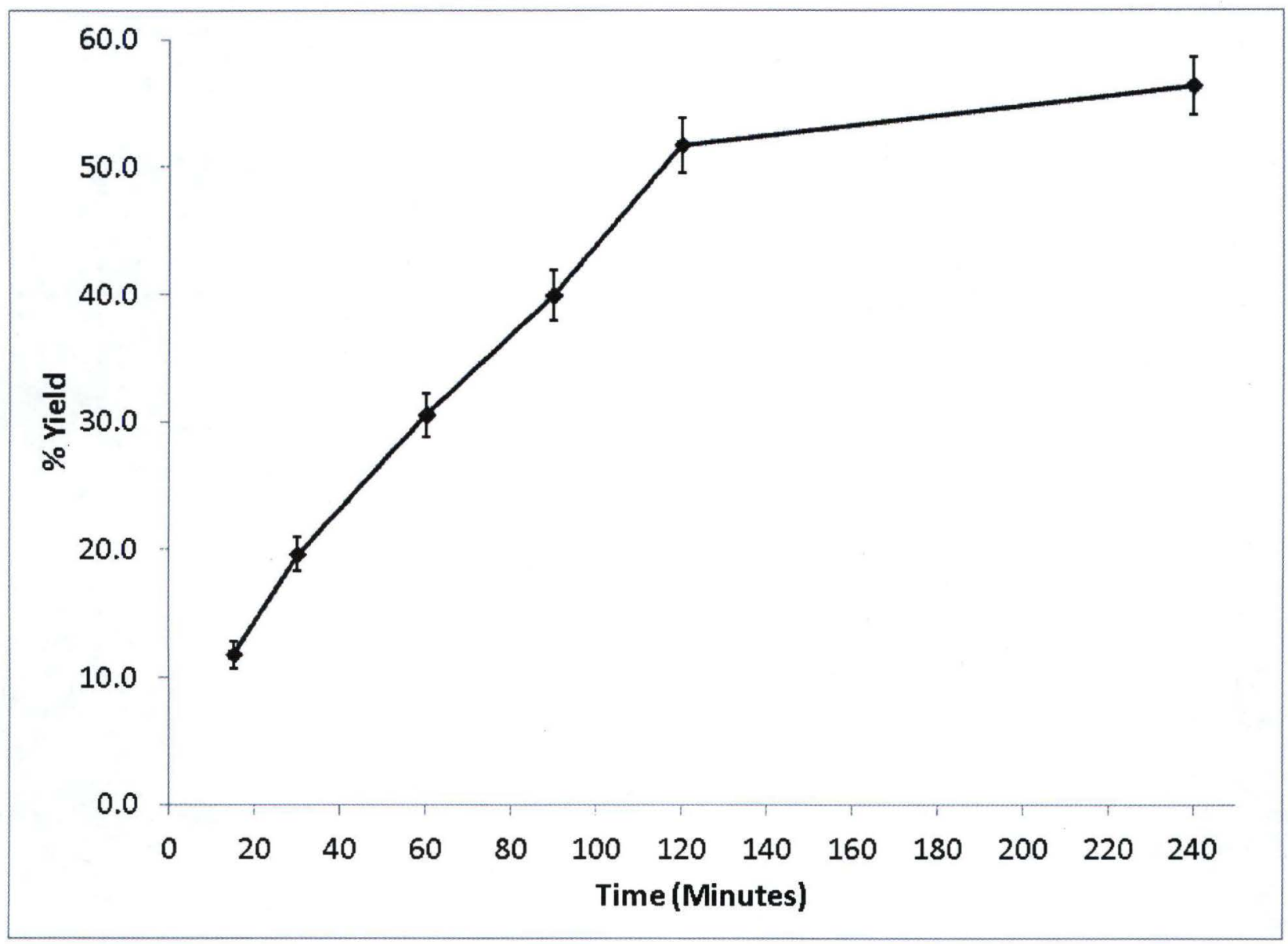


Figure 4. Graph of the change in the yield of uranium electrodeposition as a function of current for 60 and 120 minutes..

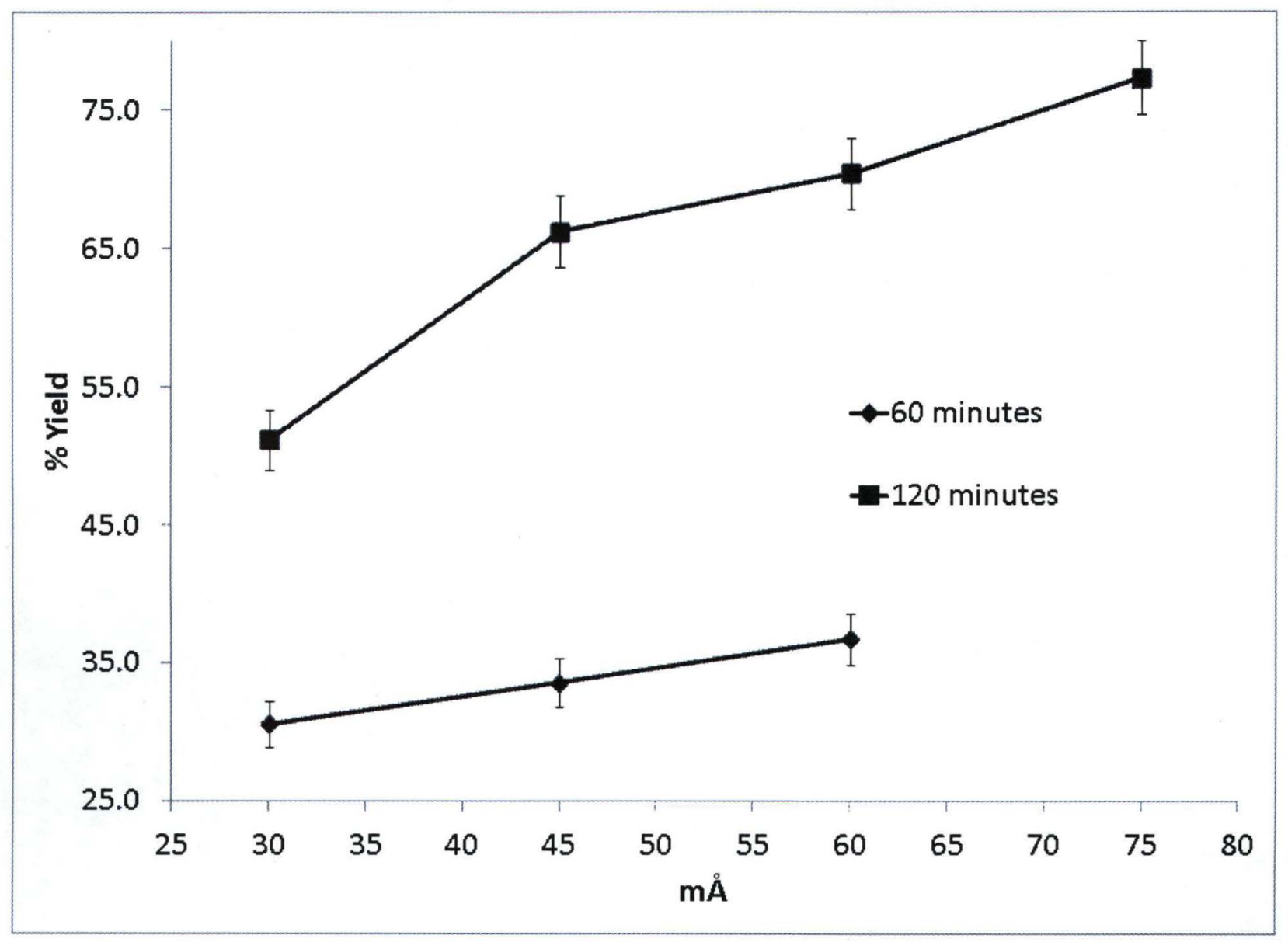


Figure 5. Graph of the change in the yield and deposit thickness of uranium electrodeposition as a function the initial amount of uranium added to the electrodeposition cell. Note that the deposit thickness is per side; the deposit thickness for one target is twice the amount given.

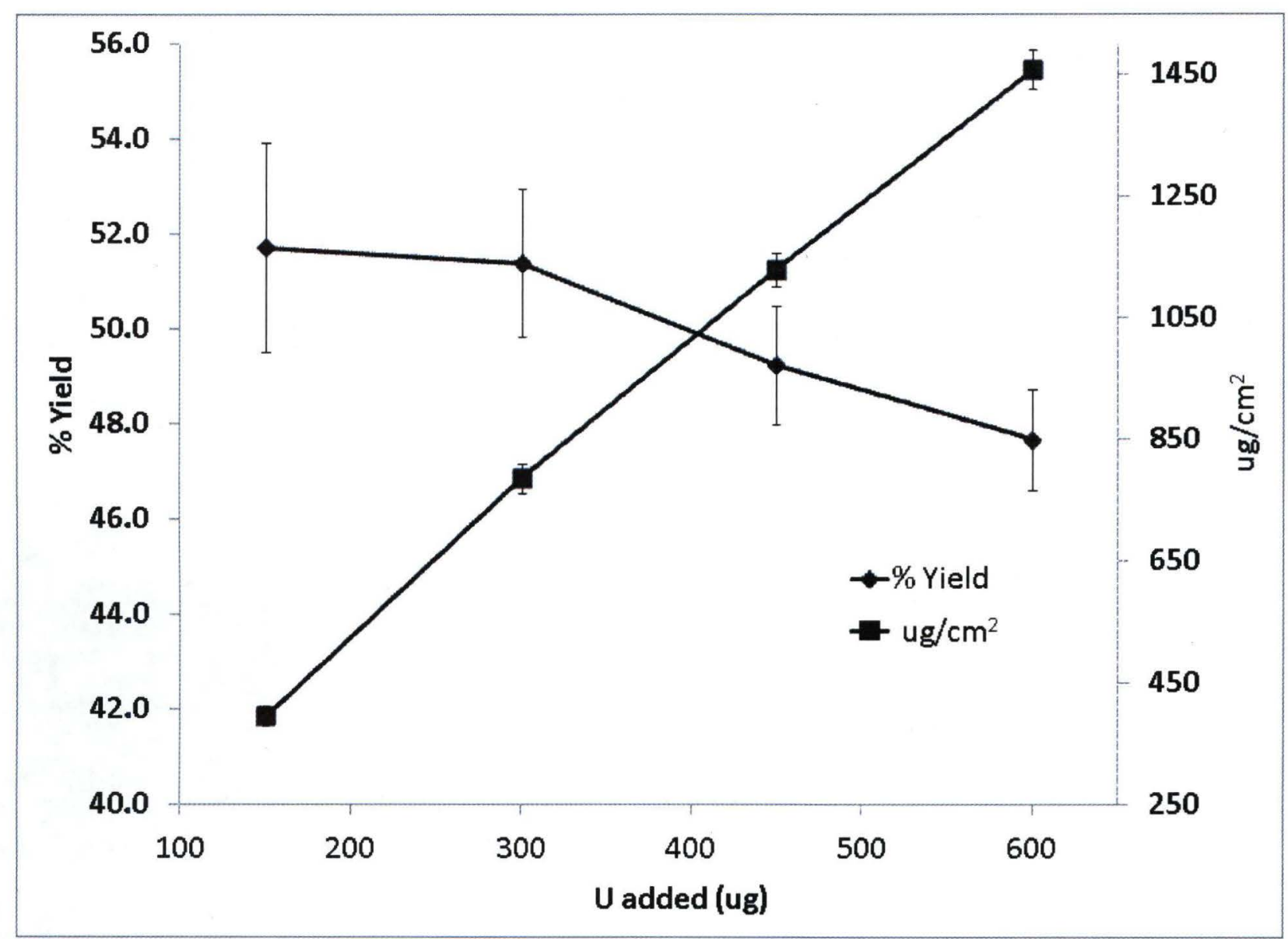


Figure 6. Autoradiograph of the uranium deposit prepared at $60 \mathrm{~m} \AA$ and 120 minutes. Note the decreased thickness of the deposit at the top.

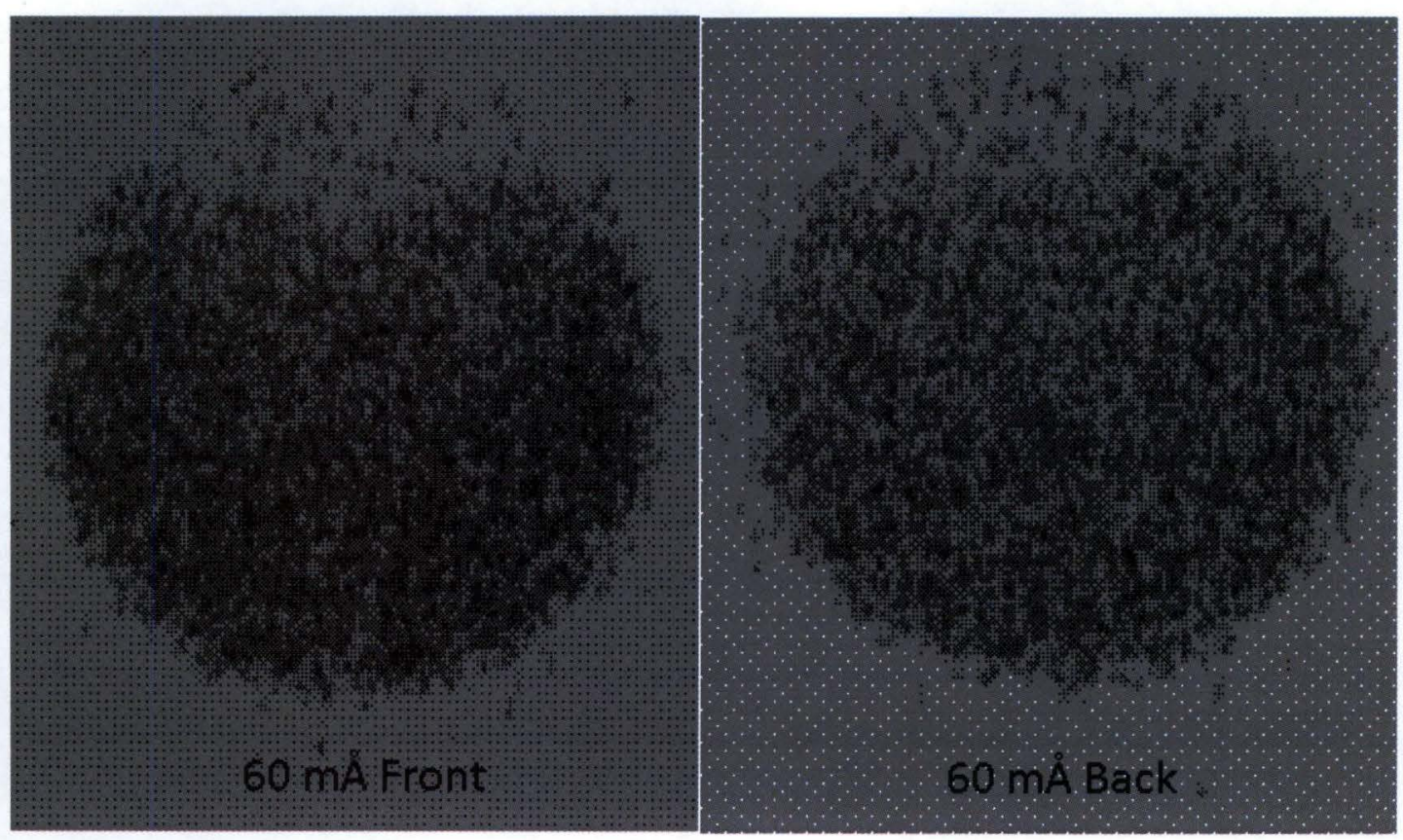


Figure 7. a. Schematic of electrodeposition cell showing placement of substrate, O-ring and wall. The area where bubbles may become trapped are shown. b. Schematic of proposed change to electrodeposition cell, which may allow bubbles formed during the electrodeposition to escape.

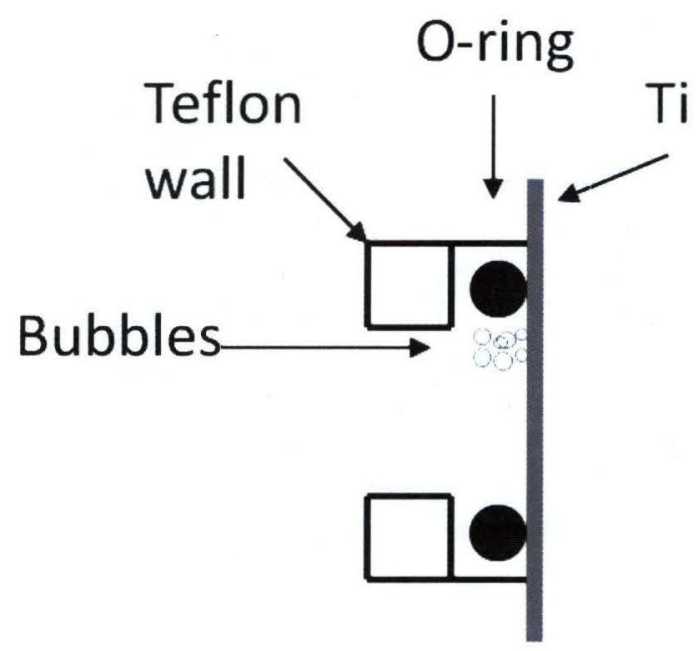

a

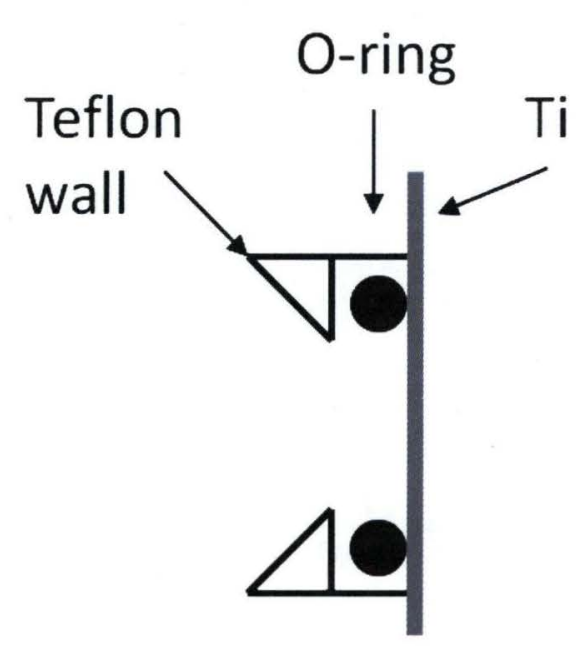

b 